\title{
Development and application of a STEAM program using classroom wall gardens
}

\author{
Hye Ran Kwack ${ }^{1}$ and Eu Jean Jang ${ }^{2 *}$ \\ ${ }^{1}$ Professor, Science \& Technology Education for Life, Seoul National University of Education, Seoul 06639, South Korea \\ ${ }^{2}$ Instructor, Science \& Technology Education for Life, Seoul National University of Education, Seoul 06639, South Korea
}

\section{ABSTRACT}

Background and objective: This study aims to develop and apply programs in agriculture and life sciences for promoting divergent thinking in STEAM using classroom wall gardens. The process of the STEAM program such as presentation of the situation, creative design, and success experience is proposed to utilize STEAM education as a distinguished program. Methods: Four types of classroom wall gardens were used in this program, such as the 'plaster pot wall garden', 'attachable LED wall garden'. 'coffee pack wall garden', and 'hanging wall garden' for each classroom. For this purpose, official letters were sent to relevant institutions (elementary schools) specified by the research institute, and classes were conducted on the selected elementary school students.

Results: A satisfaction survey and effect analysis were conducted on the students participating in the program. The program was designed to take a total of 11 hours, comprised of teaching plans including the topics, purpose of production, subject outlines, learning goals, and elements of STEAM subjects and stages.

Conclusion: According to the survey on student satisfaction and understanding, it was found that students participating in the program have a high level of understanding and participation, as well as increased interest in science. Also, the program helped the students to connect with other subject areas. The level of student satisfaction was especially high in the upper grades. It is believed that the results of this research contribute to the development of STEAM education programs in agriculture and life sciences as well as other subject areas.

Keywords: agricultural science, elementary school, STEAM education

\section{Introduction}

STEAM education begins from STEM education by adding arts (A) and covering the five areas of science, technology, engineering, arts, and mathematics (Kim, 2012). STEAM education is implemented more in elementary school than middle and high school. STEAM is already blended into the curriculums of Grades 5 and 6 with practical courses comprised of various fields such as technology, home economics, agricultural and life sciences, career, and environment (Lee and Han, 2011; Kim, 2013).

Agriculture-related education is included in technology and engineering in STEAM education of primary and secondary schools. In particular, agricultural and life sciences include all kinds of knowledge in life sciences that can be aligned with STEAM education related to plant growth, cultivation, breeding, and utilization, as well as various contents of domestic science with high learning motives differentiated from general science contents (Han and Park, 2015). However, since the emergence of STEAM in the Ministry of Education in 2011, research and education methods in life sciences have been focused on mathematics and science, whereas there are very few STEAM studies on agriculture and horticulture in Korea (Lee and Han,

Received: April 29, 2021, Revised: May 12, 2021, Accepted: July 20, 2021

First author: Hye Ran Kwack, kwack621@snue.ac.kr, (D) https://orcid.org/0000-0003-0193-2056

*Corresponding author: Eu Jean Jang, flolin@hanmail.net, (1) https://orcid.org/0000-0002-7613-1678 
2011). Virginia Tech Cooperative Extension that participated in STEM education development in the US has been actively using STEM in education programs for many years at school in the form of integrated education (Kwack et al., 2012). Elementary education settings are currently introducing wall gardens among various horticultural activities considering the diverse physical and cognitive education effects or issues such as lack of school space for gardening. Therefore, various education programs of horticulture and education experts are needed considering the educational effects and decorating methods. Accordingly, this study implemented the STEAM system as a typical convergence-based research approach to a wall garden building program that is a suitable horticultural activity for classrooms. This is applied to elementary education settings so that this study can be the basic research for extensive divergent thinking and more large-scale wall gardens. Moreover, increasing the level of understanding considering the learning stage of each grade will improve student satisfaction about STEAM education for extended application in elementary schools.

\section{Research Methods}

\section{Development of classroom wall gardens and the program}

\section{Wall garden development}

There are various wall gardens out in the market, but instead of purchasing ready-made gardens, we made them with students considering the educational effect, cost reduction, and field practicality.

For the development of classroom wall gardens, we first considered the horticultural education achievement criteria in the 2015 Revised Curriculum (www.kice.re.kr), elementary school classroom characteristics (Noh et al., 2019), plant maintenance and cultivation characteristics (Kim et al., 2012), specificity of school and behavioral characteristics of elementary children (Lee and Lim, 2019) to determine the considerations and solutions for creating classroom wall gardens. Accordingly, we analyzed previous studies on classroom gardens (Kang et al., 2020; Lee and Lee,
2020) and the considerations for creating classroom gardens as shown in Table 1 (Ku et al., 2002; Kim and Kwack, 2008). Accordingly, this study designed wall gardens using attached pots based on the three considerations (lack of classroom space, plant management responsibility, management during school holidays) and solutions in Table 1.

\section{Development of the classroom wall garden program}

Four types of materials and design for wall gardens using attachable pots designed in 1) were selected 'using various everyday materials, applying creative ideas, and using recyclables' in the interpretation of horticultural education achievement criteria in the 2015 National Curriculum (www.kice.re.kr) (Table 2). The program was to include connectivity with STEAM subjects (science, technology, engineering, arts, mathematics) (Table 2).

The STEAM-aligned program was first developed based on the premise that the four wall garden designs developed are used (Table 2). The program was organized in 8 sessions using the four wall garden designs. The guidance plan had three stages. First, a scientific inquiry-based learning model was applied to the overall guidance plan (Lee and Lim, 2001). Second, each stage of the inquiry-based learning model was aligned with the concept of STEAM thinking skills provided by the Korea Foundation for the Advancement of Science \& Creativity (www.kofac.re.kr). Third, for divergent thinking that is the key concept of STEAM education, the concepts such as presentation of the situation, creative design, and success experience derived from the first two stages are linked to open mind, thought development, and thought solidification (Kim, 2015). Therefore, the classroom wall garden program was developed as the classroom wall garden STEAM program through the learning process as shown in Fig. 1.

\section{Participants}

The program was comprised of total 8 sessions, 2 sessions for each class, targeting 270 students in 10 elementary schools in Seoul. Experts were sent to the schools to conduct class to make the most use of the institution's facilities and expert infrastructure. Moreover, STEAM teachers and horticultural experts were sent to the schools to 
Table 1. Considerations in creating school and classroom gardens

\begin{tabular}{ll}
\hline \multicolumn{1}{c}{ Considerations } & \multicolumn{1}{c}{ Solutions } \\
\hline Lack of classroom space & $\begin{array}{l}\text { Classrooms have limited floor area due to all kinds of furnishings and teaching aids. Considering this, it may } \\
\text { be a solution to put up and cultivate plants in the form of a wall garden that does not take up floor area. }\end{array}$ \\
$\begin{array}{l}\text { Plant management } \\
\text { responsibility }\end{array}$ & $\begin{array}{l}\text { When creating a garden at school or in a classroom and carrying out horticultural activities, it may be unclear } \\
\text { who (student, teacher, manager, etc.) is responsible. It is better to have students manage the garden for better } \\
\text { educational effect. Thus, it is decided that small pots will be raised so that each student can manage 2-3 pots } \\
\text { instead of creating box-type assemble planting or group containers. These must be put up as wall gardens so } \\
\text { that they are more apparent and can be observed at all times. }\end{array}$ \\
& $\begin{array}{l}\text { The biggest problem of school or classroom gardens is their management during school holidays. The gardens } \\
\text { must be created using attachable pots so that students can detach and take them home as a home project during } \\
\text { the holidays and bring them back after. }\end{array}$ \\
holidays &
\end{tabular}

Table 2. Design types and production methods of classroom wall gardens as well as correlation with STEAM elements

\begin{tabular}{|c|c|c|c|c|c|c|c|c|}
\hline \multirow{2}{*}{ Program } & \multirow{2}{*}{\multicolumn{2}{|c|}{ Design type }} & \multirow{2}{*}{$\begin{array}{l}\text { Production method and horticultural } \\
\text { education effect }\end{array}$} & \multicolumn{5}{|c|}{ Major STEAM elements } \\
\hline & & & & $\mathrm{S}$ & $\mathrm{T}$ & $\mathrm{E}$ & A & $\mathrm{M}$ \\
\hline \multirow{4}{*}{$\begin{array}{c}\text { Creating } \\
\text { classroom } \\
\text { wall gardens }\end{array}$} & \multirow{4}{*}{$\begin{array}{l}\text { Creating wall } \\
\text { gardens using } \\
\text { materials } \\
\text { around us }\end{array}$} & $\begin{array}{l}\text { Creating a plaster } \\
\text { pot wall garden } \\
\text { (succulent plant) }\end{array}$ & $\begin{array}{l}\text { Attaching pots using plaster mold, plaster, aroma } \\
\text { oil, and neodymium to a perforated metal sheet } \\
\text { Understanding the cultivation and ecology of } \\
\text { succulent plants }\end{array}$ & 0 & 0 & & $\bigcirc$ & \\
\hline & & $\begin{array}{l}\text { Creating an } \\
\text { attachable LED } \\
\text { wall garden }\end{array}$ & $\begin{array}{l}\text { Attaching pots using tin cases with attachable } \\
\text { LED and neodymium to a perforated metal sheet } \\
\text { Understanding LED as a light source of plants } \\
\text { Understanding how to make culture soil } \\
\text { Understanding the cultivation and ecology of } \\
\text { foliage plants }\end{array}$ & $\bigcirc$ & $\bigcirc$ & & & \\
\hline & & $\begin{array}{l}\text { Creating a coffee } \\
\text { pack wall garden }\end{array}$ & $\begin{array}{l}\text { Attaching pots using coffee packs, plant wicks, } \\
\text { and neodymium to a perforated metal sheet } \\
\text { Understanding how to make culture soil } \\
\text { Understanding the cultivation and ecology of } \\
\text { foliage plants }\end{array}$ & $\bigcirc$ & $\bigcirc$ & & $\bigcirc$ & \\
\hline & & $\begin{array}{l}\text { Creating a wall } \\
\text { garden using } \\
\text { vertical pots }\end{array}$ & $\begin{array}{l}\text { Hanging modular vertical pots using neodymium } \\
\text { on a rack for hangers } \\
\text { Understanding how to make culture soil } \\
\text { Understanding the cultivation and ecology of } \\
\text { arctic plants }\end{array}$ & O & & & & \\
\hline
\end{tabular}

install the classroom wall gardens with the students for class. The survey results after the program showed that, out of 270 students that participated in the program, the results of 165 students were analyzed excluding those who participated redundantly in class. There were 83 male (49.7\%) and 82 female students (50.3\%), and 25 were in Grade 3, 60 were in Grade 4, 55 were in Grade 5, and 25 were in Grade 6.

\section{Measurement tool}

\section{Items and reliability of the measurement tool}

The measurement tool used in this study was comprised of total 39 items, such as 21 items on satisfaction with program participation provided by the Korea Foundation for the Advancement of Science \& Creativity, 4 items on demographic characteristics, 8 items on satisfaction with 


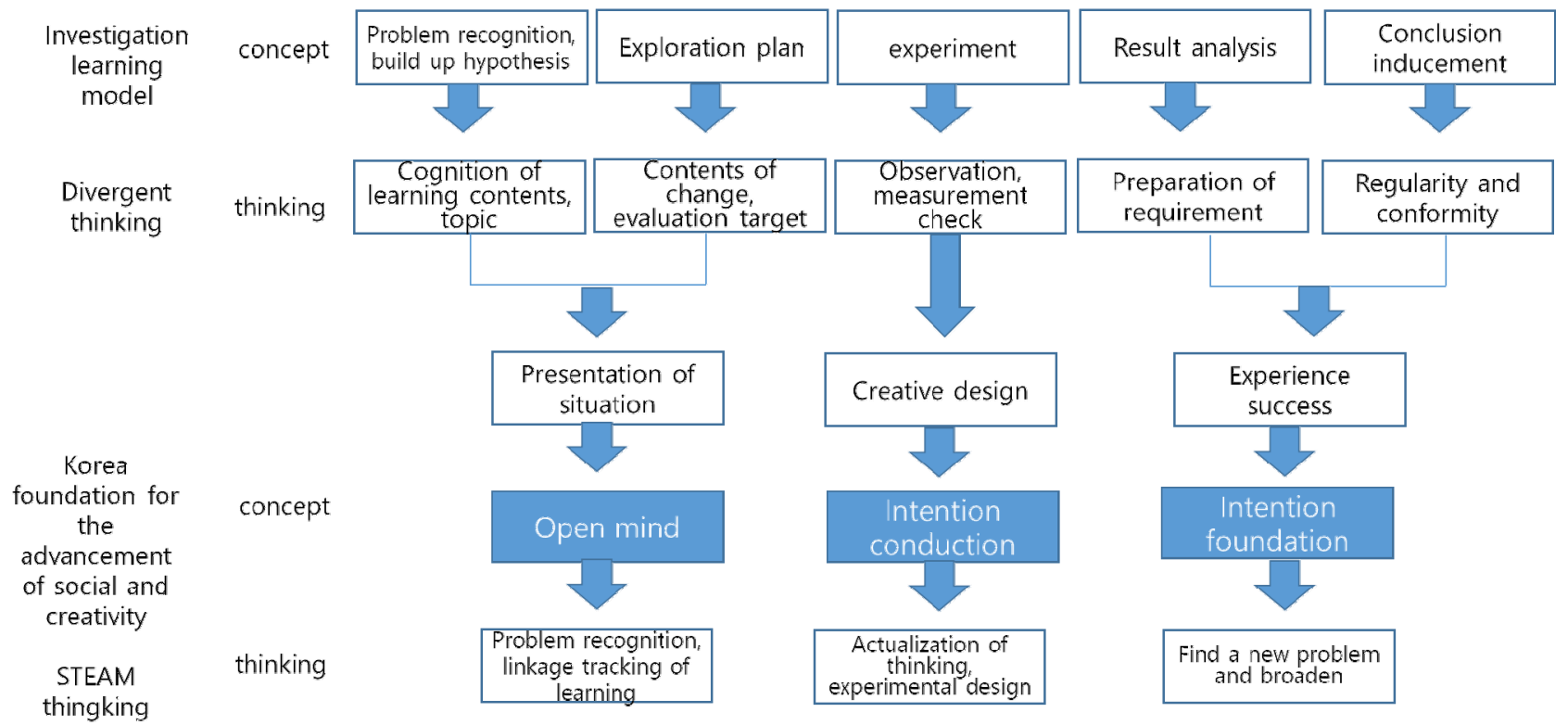

Fig. 1. Contents and three stages of the classroom wall garden STEAM program.

Table 3. Survey items by knowledge, technology, and attitude about STEAM education using classroom wall gardens

\begin{tabular}{|c|c|c|c|}
\hline Classification & Subdomain & No. of items & Reliability \\
\hline Basic statistical data & Gender, school type, grade, area & 4 & - \\
\hline Satisfaction with class & $\begin{array}{l}\text { Content, teaching method, environment, need for convergence curriculum, } \\
\text { experience, help in class, career interest, activity focused, science interest, } \\
\text { science-related career interest, my own idea, study goal, joy of learning } \\
\text { something new, problem solving }\end{array}$ & 21 & 0.791 \\
\hline \multirow{3}{*}{$\begin{array}{l}\text { Satisfaction with } \\
\text { STEAM class }\end{array}$} & Relevance to other subjects & \multirow{3}{*}{3} & \multirow{3}{*}{0.727} \\
\hline & Satisfaction with how the class is conducted & & \\
\hline & Satisfaction with where the class is conducted & & \\
\hline $\begin{array}{l}\text { Understanding of } \\
\text { STEAM class }\end{array}$ & $\begin{array}{l}\text { Understanding the concept, relevant jobs, life adaptation, career interest, } \\
\text { skill acquisition, plant interest, plant cultivation }\end{array}$ & 8 & 0.789 \\
\hline Total & & 39 & 0.802 \\
\hline
\end{tabular}

program contents, and 6 items on satisfaction with participation (Table 3). Cronbach's $\alpha$ was calculated using IBM SPSS Statistics to test the reliability of the survey items used in this study. As a result, Cronbach's $\alpha$ was .802 and the results of reliability testing for each domain of eco-friendly future agriculture are as shown in Table 3.

\section{Data analysis method}

The copies of the questionnaire collected were analyzed using the statistical program SPSS 25.0 (IBM Co, Armonk, NY, USA). Based on the learning effects of the STEAM program on elementary school students (Kim, 2016), we identified the differences depending on the background variables of the students such as gender and grade and used them as the basic data for application of the STEAM program. The means of understanding of and satisfaction with program participation and contents were compared among variables, and the satisfaction for factors showing the most significant difference was analyzed. Implications were suggested based on the summarized results. Frequency analysis was conducted to determine the general characteristics of the participants, and student satisfaction with the program by variable was analyzed using the t-test and ANOVA. The reliability of the items was calculated with 
Cronbach's $\alpha$, and the statistical significance was at 0.05 .

\section{Results and Discussion}

\section{Creating classroom wall gardens}

Classroom wall gardens are recently introduced to reduce particular matter and make classrooms green in elementary schools (Kim and Kwack, 2008). This is a greening technique that enables effective school plant education using classroom gardens, which must be widely supplied to purify the air and reduce particulate matter in classrooms (Bang et al., 2013). However, issues such as the educational effect of wall gardens or sustainability such as management and cost have been raised. This study encouraged students to create and implement classroom wall gardens in learning, which are easy to manage and relatively less expensive, and use them as a learning tool. Wall gardens created in this study were literally 'classroom wall gardens' different in size and concept from general gardens, which are created by students and used in class from completion to management (Kang, 2006). The materials used were those specified in the 2015 National Curriculum or everyday life materials and recyclables that are easily found in daily life. The plants chosen were also popular and inexpensive types. The design method was developed in the form of 'attachable pots' considering the difficulties in plant management in school settings, or the specificity and characteristics of elementary school students based on previous research (Bang et al., 2013). Table 4 shows the characteristics of materials and completed forms of classroom wall gardens. The classroom wall gardens completed considering the specificity of elementary schools and children's behaviors had a few advantages differentiated from general wall gardens. First, students can create and modify the gardens any way they want. Second, these gardens can be managed during school holidays and take up less classroom space. Third, the gardens reflect the characteristics of learning materials specified in the curriculum and are decorated using everyday life materials or recyclables. Fourth, when implementing actual air-purifying wall gardens, these gardens can be used for prior learning or an educational tool to facilitate the understanding of garden plants, wall gardens, and garden management (Fig. 2). The materials and characteristics of each classroom wall garden based on these advantages are as summarized in Fig. 2.

The materials used to create these classroom wall gardens are as shown in Fig. 3, which can also be used as a reference for creating other classroom gardens in the future.

\section{Development of the STEAM program using classroom wall gardens}

The essential guidance plan to implement the wall gardens in the actual settings was developed so that they can be immediately applied as a STEAM education program in the school settings using the STEAM program framework as convergence education.

Table 5 shows the results of combining the inquiry-based learning model with the STEAM thinking skills model provided by the Korea Foundation for the Advancement of Science \& Creativity as shown in Fig. 1. This guidance plan was than aligned with the stages of divergent thinking (open mind - thought development - thought solidification) that is the core thinking of STEAM education (Hong and Yoo, 2016). We developed total 4 classes in 8 sessions by aligning the program with subjects related to STEAM mentioned in Tables 1 and 2 and creating a plaster pot wall garden, an attachable LED wall garden, a coffee pack wall garden, and a hanging wall garden including the STEAM learning frame of reference. The program was then developed into the form of a guidance plan for school studies, which was designed as shown in Table 4 considering the STEAM education framework and divergent thinking combined with the inquiry-based learning model used typically to explore scientific thinking skills in school settings. The stages of 'problem awareness and hypothesis testing' and 'exploration plan' in the inquiry-based learning model 'presented the situation' in which students can learn diverse thinking skills and whether they can solve problems accordingly and lead to an 'open mind' in facing new problems. In the 'experiment stage', they were to make 'creative designs' and 'develop various thoughts' through the experiment. In the 'result analysis and conclusion' 


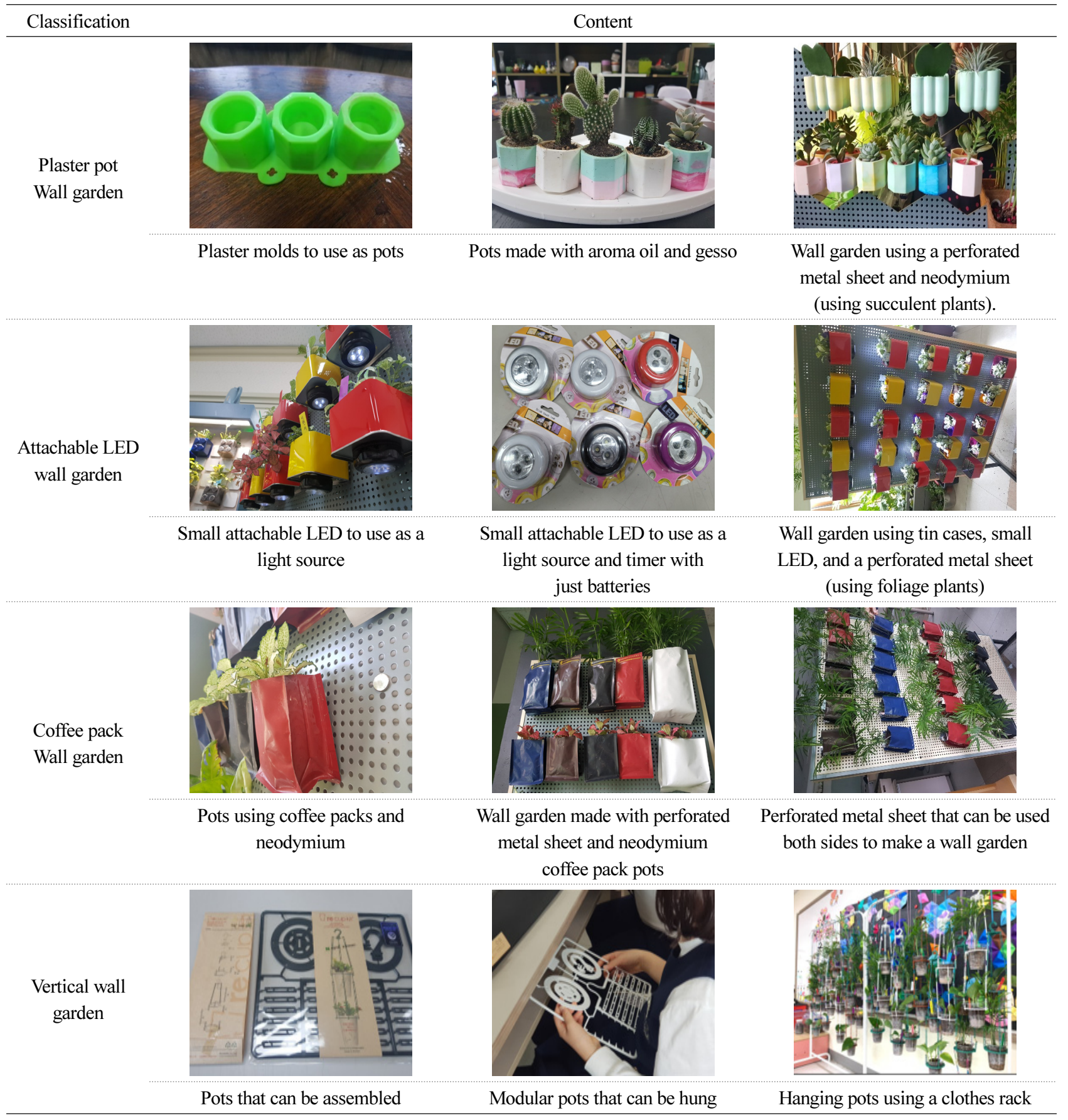

Fig. 2. Materials and characteristics of each classroom wall garden.

stages, they could 'solidify their thoughts' towards a more open mind based on 'success experience' about the studies they have done so far (Hong and Yoo, 2016). For example, the wall garden using 'attachable LED pots' taught students to understand the correlation between the scientific characteristics of LED as a light source for plant growth with cultivation of foliage plants and to know that they can cre- ate various designs of wall gardens (presentation of the situation-open mind). They could also experience STEAMbased thinking aligned with creation of an LED wall garden using attachable LED, tin cases, and a perforated metal sheet (creative design - thought development), comparison of observation journals for LED pots and regular lighting pots, and methods to create various classroom wall gardens 


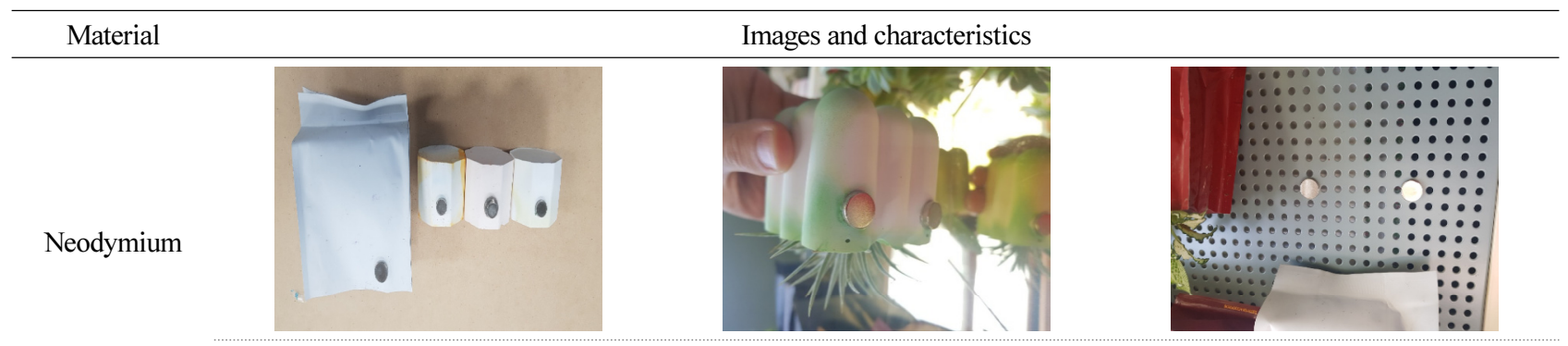

Neodymium is a powerful magnet that can stick the pots on a perforated metal sheet to create a wall garden. Since it is a powerful magnet, extra care is needed from students when using it in school settings.

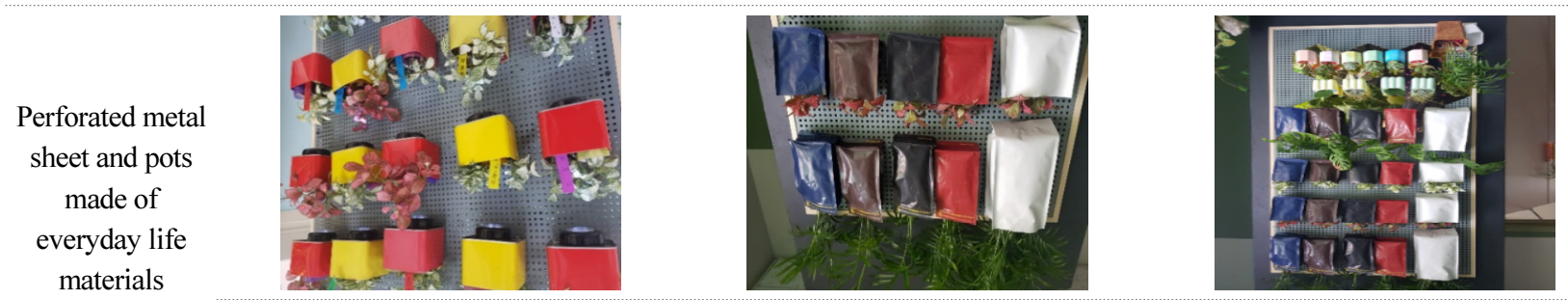

Light everyday life materials such as tin cases or coffee packs can be used as attachable pots. It is necessary when considering personal management by student at school or considering moving the pots (home project) during school holidays.

Fig. 3. Materials used to create classroom wall gardens.

Table 4. Main contents and three stages of the classroom wall garden program

\begin{tabular}{|c|c|c|c|c|c|}
\hline \multirow{4}{*}{ Program } & \multicolumn{5}{|c|}{ Main contents and stages } \\
\hline & $\begin{array}{l}\text { Problem awareness } \\
\text { and hypothesis setting }\end{array}$ & Exploration plan & Experiment & Result analysis & Conclusion \\
\hline & \multicolumn{2}{|c|}{ Presentation of the situation } & Creative design & \multicolumn{2}{|c|}{ Success experience } \\
\hline & \multicolumn{2}{|c|}{ Open mind } & $\begin{array}{c}\text { Thought } \\
\text { development }\end{array}$ & \multicolumn{2}{|c|}{$\begin{array}{c}\text { Thought } \\
\text { solidification }\end{array}$} \\
\hline $\begin{array}{l}\text { Creating a } \\
\text { plaster pot } \\
\text { wall garden }\end{array}$ & $\begin{array}{l}\text { Carrying out } \\
\text { gardening activities } \\
\text { using design }\end{array}$ & $\begin{array}{l}\text { Understanding the } \\
\text { ecological environment } \\
\text { of succulent plants } \\
\text { Finding out how to } \\
\text { make plaster pots }\end{array}$ & $\begin{array}{l}\text { Creating a wall } \\
\text { garden using plaster } \\
\text { mold pots and a } \\
\text { perforated metal } \\
\text { sheet }\end{array}$ & $\begin{array}{l}\text { Writing an observation } \\
\text { journal of plaster pot } \\
\text { succulent plants }\end{array}$ & $\begin{array}{l}\text { Finding out various ways } \\
\text { to create a classroom } \\
\text { wall garden } \\
\text { Finding out how to grow } \\
\text { succulent plants }\end{array}$ \\
\hline $\begin{array}{l}\text { Creating an } \\
\text { attachable } \\
\text { LED } \\
\text { wall garden }\end{array}$ & $\begin{array}{l}\text { Finding out the } \\
\text { concepts and } \\
\text { relevance of LED } \\
\text { and plant growth }\end{array}$ & $\begin{array}{l}\text { Understanding the } \\
\text { scientific principles in } \\
\text { which LED affects plant } \\
\text { growth } \\
\text { Understanding the } \\
\text { ecological environment } \\
\text { of foliage plants }\end{array}$ & $\begin{array}{l}\text { Creating a wall } \\
\text { garden using } \\
\text { attachable LED, tin } \\
\text { cases, and a } \\
\text { perforated metal } \\
\text { sheet }\end{array}$ & $\begin{array}{l}\text { Writing an observation } \\
\text { journal of LED pots } \\
\text { and foliage plants }\end{array}$ & $\begin{array}{l}\text { Finding out various ways } \\
\text { to create a classroom } \\
\text { wall garden } \\
\text { Finding out the light } \\
\text { sources for plants }\end{array}$ \\
\hline $\begin{array}{l}\text { Creating a } \\
\text { coffee pack } \\
\text { wall garden }\end{array}$ & $\begin{array}{l}\text { Thinking about } \\
\text { gardening activities } \\
\text { using recyclables }\end{array}$ & $\begin{array}{l}\text { Understanding the } \\
\text { ecological effect of } \\
\text { gardening activities } \\
\text { Using recyclables as } \\
\text { gardening tools } \\
\text { Understanding the } \\
\text { ecological environment } \\
\text { of foliage plants }\end{array}$ & $\begin{array}{l}\text { Creating a wall } \\
\text { garden using coffee } \\
\text { packs, tin cases, and } \\
\text { a perforated metal } \\
\text { sheet }\end{array}$ & $\begin{array}{l}\text { Making a table of } \\
\text { observation of } \\
\text { coffee pack pot } \\
\text { foliage plants }\end{array}$ & $\begin{array}{l}\text { Finding out various ways } \\
\text { to create a classroom } \\
\text { wall garden } \\
\text { Finding out various } \\
\text { gardening tools that can } \\
\text { be made with recyclables }\end{array}$ \\
\hline $\begin{array}{l}\text { Creating a } \\
\text { vertical wall } \\
\text { garden }\end{array}$ & $\begin{array}{l}\text { Thinking about } \\
\text { creating a garden } \\
\text { making practical use } \\
\text { of space }\end{array}$ & $\begin{array}{l}\text { Planning a garden } \\
\text { suitable for indoor space } \\
\text { Understanding the } \\
\text { ecological environment } \\
\text { of arctic plants }\end{array}$ & $\begin{array}{l}\text { Creating a hanging } \\
\text { wall garden using a } \\
\text { clothes rack }\end{array}$ & $\begin{array}{l}\text { Writing an observation } \\
\text { journal of hanging } \\
\text { pot plants }\end{array}$ & $\begin{array}{l}\text { Finding out about } \\
\text { modular pots } \\
\text { Finding out various ways } \\
\text { to grow air plants }\end{array}$ \\
\hline
\end{tabular}


Table 5. Comparison of understanding of the STEAM program using classroom wall gardens by gender

\begin{tabular}{ccccccc}
\hline & Classification & No. of students & Mean & Standard deviation & $\mathrm{t}$ & $p$ \\
\hline \multirow{2}{*}{ Understanding } & Male & 83 & 13.7831 & 1.69683 & \multirow{2}{*}{.607} & $.684^{\text {NS }}$ \\
& Female & 82 & 13.6707 & 1.84628 & & \\
\hline
\end{tabular}

Table 6. Comparison of understanding of the STEAM program using classroom wall gardens by grade

\begin{tabular}{ccccccc}
\hline & Classification & No. of students & Mean & Standard deviation & F & $p$ \\
\hline \multirow{4}{*}{ Understanding } & Grade 3 & 19 & $9.1579^{\mathrm{a}}$ & .68825 & & \\
& Grade 4 & 70 & $14.3714^{\mathrm{b}}$ & .48668 & 394.567 & $p<.001^{* * *}$ \\
& Grade 5 & 52 & $14.4038^{\mathrm{b}}$ & .84621 & .00000 & \\
& Grade 6 & 24 & $14.0000^{\mathrm{b}}$ & & \\
\hline
\end{tabular}

${ }^{* * *} p<.001$ by one way ANOVA, $\mathrm{a}<\mathrm{b}$ by Scheffe.

(success experience - thought solidification) (Table 4).

\section{Satisfaction with the STEAM program using classroom wall gardens}

\section{Understanding of the program}

The results of conducting the t-test and ANOVA to compare student understanding of class applying the STEAM program with classroom wall gardens by gender and grade are as follows. Students showed a high level of understanding regardless of gender, and there was no statistical difference by gender.

A study developing a STEAM-based elementary education program for the gifted (Lee, 2012) was also conducted on Grade 6 students without considering gender. Studies on art programs using STEAM education (Kwack and Kim, 2019) or guidance plans focused on the art subject using STEAM education (Kim, 2016) also did not show a difference by gender, indicating that there were few considerations for gender in applying STEAM programs to elementary schools.

Female students tended to show a high level of interest, understanding, and preference for general classroom horticultural programs (Kim et al., 2002; Song, 2008), but the understanding of the STEAM program using classroom wall gardens in this study was high regardless of gender. This indicates that STEAM programs related to horticultural activities such as making plaster pots, using LED, and making modular pots on perforated metal sheets added more scientific and mathematical knowledge, and thus male students tended to show high preference and understanding.

Understanding of the STEAM program using classroom wall gardens varied among grades, showing that Grades 4, 5, and 6 students had a better understanding than Grade 3 students (Table 6). This proved that STEAM education for Grade 3 students who are just moving up from the lower grades of elementary school (Grades 1 and 2) must be newly established to meet the level of Grade 3 students. As suggested by a study on the guidance plan focused on the art subject using STEAM education (Kim, 2016) which revealed the difference by grade, it is necessary to consider different methods, cases, materials, and participants of the program for each grade to promote understanding of STEAM education using classroom wall gardens.

\section{Satisfaction with the program}

The results of conducting the t-test and ANOVA to compare student satisfaction with class applying the STEAM program with classroom wall gardens by gender and grade are as follows (Tables 7,8). Students showed a high level of satisfaction, and there was no statistical difference in satisfaction by gender.

A study on the development and effects of a STEAM program focused on the art subject for elementary school students (Kim et al., 2016) also did not prove the difference in program satisfaction by gender, and the overall satisfaction was high and thus applying the program to elementary school was found effective. As such, this study 
Table 7. Comparison of satisfaction with the STEAM program using classroom wall gardens by gender

\begin{tabular}{cccccccc}
\hline & Classification & No. of students & Mean & Standard deviation & $\mathrm{t}$ & $\mathrm{p}$ \\
\hline \multirow{3}{*}{ Satisfaction } & Male & 83 & 28.8554 & 6.35175 & .179 & $.858^{\mathrm{NS}}$ \\
& Female & 82 & 28.6707 & 6.87464 & .179 & $.858^{\mathrm{NS}}$ \\
\hline
\end{tabular}

NS $>.05$ by t-test

Table 8. Comparison of satisfaction with the STEAM program using classroom wall gardens by grade

\begin{tabular}{ccccccc}
\hline & Classification & No. of students & Mean & Standard deviation & F & $p$ \\
\hline \multirow{4}{*}{ Satisfaction } & Grade 3 & 19 & $16.736^{\mathrm{a}}$ & 3.211 & & \\
& Grade 4 & 70 & $27.000^{\mathrm{b}}$ & 4.270 & 52.846 & $p<.001^{* * *}$ \\
& Grade 5 & 52 & $29.8462 \mathrm{~b}^{\mathrm{c}}$ & 3.566 & & \\
& Grade 6 & 24 & $31.8286^{\mathrm{c}}$ & 6.326 & & \\
\hline
\end{tabular}

${ }^{* * *} p<.001$ by one way ANOVA, $\mathrm{a}<\mathrm{b}<\mathrm{c}$ by Scheffe.

also did not show a difference in program satisfaction by gender, indicating that it is not necessary to consider development and application of programs based on gender differences.

In the program comprised of total 23 items, satisfaction with the program contents in all items except Items 2 and 3 showed a statistical difference by grade. Satisfaction with STEAM education was higher in Grades 4, 5, and 6 than Grade 3, which shows the same result as understanding and proving that there is a difference in satisfaction with STEAM education overall depending on grade. Therefore, one way to increase student satisfaction with STEAM in elementary school is to consider the difficulty and topic of the program by grade. A study on the development and effect of STEAM programs for entrepreneurship of Grades 3-4 in elementary school also showed that there was a difference between Grade 3 and Grade 4, indicating that it is necessary to implement different programs by grade (Lim, 2017). Unlike other wall garden programs for schools, the wall garden program used in this study showed high program satisfaction among Grades 5 and 6, which is because STEAM is convergence of science, technology, engineering, arts, and mathematics (Kim, 2012), and the practical courses studied by Grades 5 and 6 in elementary school are comprised of various fields such as technology, home economics, agricultural and life sciences, career, and environment, with STEAM already blended into the curriculum (Lee and Han, 2011; Kim, 2013). Thus, student satisfaction was high in Grades 5 and 6 in which practical
Table 9. Correlation analysis between understanding of and satisfaction with the program

\begin{tabular}{ccc}
\hline Classification & Understanding & Satisfaction \\
\hline Understanding & - & .79 \\
Satisfaction & .79 & - \\
\hline
\end{tabular}

courses are provided.

There was a high correlation between understanding and satisfaction, with better understanding of the program indicating higher satisfaction with the program (Table 9).

Based on these results, it seems that increasing the level of understanding considering the learning stages of each grade would be a good way to increase student satisfaction with STEAM education and extend the application in elementary schools.

\section{Program preference}

As a result of examining the program preference for the four types of classroom wall gardens by grade, it was found that the difference in the preference by grade was statistically significant in the plaster pot garden and vertical wall garden (Table 10). This indicates that there is a difference in programs preferred by each grade and that it is necessary to consider the different grades in applying STEAM programs using classroom wall gardens. The preference was high in the attachable LED garden and coffee pack garden, but there was no difference by grade. This indicates that it is necessary to differentiate the level of each grade to 
Table 10. Preference for 4 types of classroom wall gardens by grade

\begin{tabular}{|c|c|c|c|c|c|c|}
\hline Wall garden type & Grade & No. of students & Mean & Standard deviation & $\mathrm{F}$ & $p$ \\
\hline \multirow{5}{*}{ Plaster pot } & Grade 3 & 19 & $15.21^{\mathrm{a}}$ & 3.145 & \multirow{5}{*}{49.146} & \multirow{5}{*}{$p<.001^{* * *}$} \\
\hline & Grade 4 & 70 & $18.34^{\mathrm{a}}$ & 2.814 & & \\
\hline & Grade 5 & 52 & $28.36^{\mathrm{b}}$ & 5.179 & & \\
\hline & Grade 6 & 24 & $29.18^{\mathrm{b}}$ & 2.187 & & \\
\hline & Total & 165 & & & & \\
\hline \multirow{5}{*}{$\begin{array}{l}\text { Attachable } \\
\text { LED }\end{array}$} & Grade 3 & 19 & 23.125 & 4.245 & \multirow{5}{*}{36.125} & \multirow{5}{*}{.082} \\
\hline & Grade 4 & 70 & 26.175 & 3.845 & & \\
\hline & Grade 5 & 52 & 25.841 & 5.021 & & \\
\hline & Grade 6 & 24 & 26.879 & 4.962 & & \\
\hline & Total & 165 & & & & \\
\hline \multirow{5}{*}{ Coffee pack } & Grade 3 & 19 & 26.312 & 5.654 & \multirow{5}{*}{38.272} & \multirow{5}{*}{.067} \\
\hline & Grade 4 & 70 & 27.123 & 2.856 & & \\
\hline & Grade 5 & 52 & 28.531 & 6.102 & & \\
\hline & Grade 6 & 24 & 28.945 & 5.749 & & \\
\hline & Total & 165 & & & & \\
\hline \multirow{5}{*}{$\begin{array}{l}\text { Vertical wall } \\
\text { garden }\end{array}$} & Grade 3 & 19 & 19.184 & 2.489 & \multirow{5}{*}{48.243} & \multirow{5}{*}{$.012^{*}$} \\
\hline & Grade 4 & 70 & 20.175 & 5.645 & & \\
\hline & Grade 5 & 52 & 28.645 & 2.896 & & \\
\hline & Grade 6 & 24 & 29.121 & 3.874 & & \\
\hline & Total & 165 & & & & \\
\hline
\end{tabular}

${ }^{* * *} p<.001$ by one way ANOVA, $\mathrm{a}<\mathrm{b}$ by Scheffe.

develop and apply classroom wall garden programs for STEAM.

\section{Conclusion}

The program used in this study was classroom planterior (plant + interior) based on STEAM divergent thinking. We planned various designs of the program, applied them to school settings, and analyzed student satisfaction. We chose wall gardens among various horticultural programs and narrowed the scope to classroom wall gardens, considering the practicality of using at school in terms of utility, price, and maintenance. The main focus of the program is to create classroom wall gardens, and each session was comprised of the STEAM thinking skills model based on the inquiry-based learning model for divergent thinking, aligned with STEAM thinking skills in three stages. The developed program was in four classes. The program has three characteristics. First, it is a horticultural program applying horticultural activities to STEAM education and using learning models. Second, it selected classroom wall gardens among various horticultural activities with materials and plants that are easily found in everyday life instead of full-scale wall gardens like system biowalls and aligned them with STEAM education. Therefore, this program can lead to various versions 52 . Horticultural programs in this form have opened up a new field of research that has not been considered before in horticultural activities as well as other STEAM education programs. The results can be used as a reference in horticultural education or other STEAM studies in the future. As a result of surveying student satisfaction and understanding, both male and female students showed high levels of understanding and satisfaction, without a statistically significant difference by gender. As a result of comparing student satisfaction and understanding by grade, students in Grades 4, 5, and 6 showed higher levels of understanding and satisfaction than 
Grade 3, indicating that there was a difference by grade. This is because upper-grade students had a better understanding of horticultural activities since they learn science or practical courses. As a result of conducting ANOVA to determine student satisfaction with the contents of the STEAM program by grade outside of school, there was a statistically significant difference by grade in all 21 items of satisfaction except Items 2 and 3. Thus, as Grades 4, 5 , and 6 showed higher levels of understanding and satisfaction than Grade 3, there is a difference in satisfaction with the contents of STEAM education by grade. Therefore, considering the difficulty and topic of STEAM program for each grade of elementary school will bring positive results to students' interest, satisfaction and understanding of STEAM.

\section{References}

Bang, S.W., J.A. Kim, J.E. Song, K.J. Kim, and D.W. Kim. 2013. Effect of improving indoor air quality by bio green wall system. J. Korean Soc. Hortic. Sci. Vol.31(Suppl. I):204-204.

Hong, J.H., and M.H. Yoo. 2016. The effect of program for the gifted based on GI-STEAM model on leadership, creative personality, and learning flow of elementary gifted students. J. Korean Soc. Gifted Talent. 26(1): 77-79. https://doi.org/10.9722/JGTE.2016.26.1.77

Han, H.S., and H.J. Park. 2015. A study on the development and application of a framework for STEAM program J. Learn. Cent. Curric. Inst. 15(6):41-64.

Lee, C.H. 2012. Smart Learning Strategies for STEAM Education. J. Korean Pract. Arts Educ. (KPAE) 25(4): 123-147.

Lee, C.H., and S.K. Han. 2011. Development of Practical Arts-Centered Model for STEAM Education. J. Korean Pract. Arts Educ. (KPAE) 24(4): 139-161.

Lee, D.S., and G.S. Lim. 2019. Opinions of Elementary School Teachers in Gyeonggi Province on a Support System for Students of Low Academic Achievement. J. Culture Educ. 25(1):449-470. https://doi.org/ 10.2415 9/joec.2021.27.2.311

Lee, J.S., and S.H. Lee. 2020. The effects of school gar- dening activities on scientific exploration ability and attitude to science of elementary school students. J. Fish. Mar. Sci. Educ. 32(6):1558-1570. https://doi.org/10.130 00/JFMSE.2020.12.32.6.1558

Lee, Y.A., and C.S. Lim, 2001. Effects of In-depth Science Learning Through Multiple Intelligence Activities an the Science Inquiry Abilities and Interests of Elementary School Children. J. Korean Elementary Sci. Educ. 20(2):239-254.

Lim, K.W. 2017. A Study on the Correlation between Self-Esteem and Interpersonal Stress for Children in the Low-Income Bracket. J. Korean Child Protection. 2(2):1-26.

Noh, W.K., J.S. Park, T.G. Oh, S.H. Choi, and H.W. Lee. 2019. An Analysis of the Cultural Characteristics of Elementary School Classrooms Based on Delphi technique. J. Curric. Stud. 22(2):213-242. https://doi.org/10.22799/j ce.2019.22.2.009

Kang, M.Y., H.S. Moon, J.U. Ju, S.J. Kim, and M.R. Heo. 2020. The status of plants planted in the school gardens of elementary schools in Geoje-city, Gyeongsangnam-do. J. Korean Isl. 32(1):173-187.

Kang, Y.H. 2006. Modularization of indoor gardens suitable for elementary classrooms. Master's thesis, Seoul National University of Education, Seoul, Korea.

Kim, J.Y., and H.R. Kwack. 2008. The influence of establishing indoor garden in the elementary school classroom on student's playing characteristics and patterns. J. Korean Pract. Arts Educ. 21(3):201-221.

Kim, H.I. 2015. A study on intersection of sense with problem solving for the creative design education. J. Korean design Knowledge 33:79-88. https://doi.org/10.1 7246/jkdk.2015..33.008

Kim, H.J., H.Y. Sim, and S.H. Jo. 2016. A study on the development of STEAM program with primary school fine arts curriculum as the center. J. Prod. Res. 34(1): 43-52. https://doi.org/10.36345/kacst.2016.34.1.004

Kim, H.S. 2012. A Study on Relation and Importance of Art Education and STEAM Education. J. Basic Des. Art. 13(5):105-113.

Kim, J.S., S.H. Cho, and H.G. Kim. 2002. The Effect of Classroom Horticulture Program on Academic Achievement in Practical Arts. J. Korean Pract. Arts Educ. (SKPAE) 8(1):23-33. 
Kim, M.J. 2016. Study of arts subject-centered instruction method utilizing STEAM : focused on primary high-grade students. Master's thesis, Jeju University, Jeju, Korea.

Kim, S.J., S.G. Lee, and K.S. Kim. 2012. Current Research Trend of Postharvest Technology for Chrysanthemum. J. Korean Plant Res. 25(1):156-168.

Kim, Y.J. 2013. Development of a Elementary Design Education Process for STEAM Education through a Rhetorical Approach Method. J. Basic Des. Art 14(6):37-45.

Kwack, H.R., and S.A. Kim. 2019. The Analysis of Educational Effect of The Horticultural Picture Books Focused on B.S. Bloom's Taxonomy of Educational Objectives. J. Korean Soc. Flor. Art Des. 41(41):155-169.

Kwack, H.R., E.J. Jang, and H.Y. Lee. 2012. Analysis of
Characteristics and Preference of Horicultural Activities and Plants of Multicultural Children. J. Korean Soc. People Plants Environ. 15(5):337-348.

Ku, J.Y., S.Y. Kim, M.K. Jo, and K.C. Son. 2002. Effect of setting of interior landscape at the elementary school classroom on school bullying and attention of children. J. Korean Soc. Hortic. Sci. Vol. 21(Suppl. II): 127-127. Song, D.Y. 2008. Effect of the classroom Horticultural Program on Elementary School Student's Self-esteem and Peer-relationships. Master's thesis, Chungju National University of Education, Chungju, Korea.

https:/www.kice.re.kr/main.do?s=kice

https://www.kofac.re.kr/web/main/index.do 